Gynaecologia 1955;139:239

\title{
Die Wirkung von Chinin auf den menschlichen Uterus
}

\begin{tabular}{|l|l|l|}
\hline H. & & Sauter \\
\hline J. & & Jenny \\
\hline
\end{tabular}

Zürich

(Publikation des Vortrages erfolgte in der Schweiz. medizin. Wochenschrift Nr. 48/1954 S. 1341.) 